\title{
Production Planning and Raw Materials Supply to Meet Fluctuative Demand for Livestock Feed Flour
}

\author{
Zainal Arief \\ Doctoral Student of Economics, \\ University of 17 Agustus 1945 Surabaya \\ Ida Aju Brahmasari \\ Lecturer of Faculty of Economics, \\ University of 17 Agustus 1945 Surabaya \\ Anis Eliyana \\ Lecturer of Faculty of Economics and Business, \\ Airlangga University Surabaya

\section{Fahrul Rozi \\ Private Sector}

\begin{abstract}
Production is creating goods and services, CV Bulu Nusantara is a company that processes poultry feathers, fish bones, beef bones, shells into dough flour for livestock feed. Sometimes these companies encounter overproduction and sometimes production shortages. The researcher intends to run production planning and raw material need planning that can meet fluctuative demand and minimize production costs with JIP and MRP approaches. From the research carried out, obtained forecasting demand result for period June 2017 - May 2018 for feather flour, fish flour, bone meal and crab flour for $191,040 \mathrm{~kg}, 144,876 \mathrm{~kg}, 135,189 \mathrm{~kg}$ and $158,028 \mathrm{~kg}$. From production master schedule made based on forecasting and production capacity result, a plan is obtained for June 2017 - May 2018 of Rp. 1,858,057,638. Material requirements planning (MRP) can be seen when, how many orders, how many times the order for raw materials is within 1 year, so that the raw material inventory is optimal in accordance with the master production schedule, in addition to MRP also obtained for the total cost of raw materials for planning period June 2017 - May 2018 amounting to Rp. $16,710,197,190$. From the cost of labor and raw materials, total production planning is Rp. 18,568,254,838, if the total cost of production planning is compared to the total production costs of the company in 2016-1017 amounting to $R p .18,690,250,000$ then the difference in annual production costs of $R p .121,995,170$. This means that by implementing JIP and MRP systems the company will save production costs by Rp. $121,995,170$.
\end{abstract}

Keywords: production planning, raw material inventory, JIP, MPS, MRP.

\section{INTRODUCTION}

Production is creating goods and services (Render, Heizel, 2001) operations management is an activity that makes goods and services through changes and inputs into outputs. CV Bulu Nusantara is a company that processes poultry feathers, fish bones, beef bones, shells into dough flour for animal feed. The Company began operations in 2004, located in Gresik, East Java. This company distributes products sold to livestock feed companies such as Pokphand, Japfa, etc. The need for livestock feed flour will never stop, giving rise to fluctuating demand. The company currently has not made demand forecasting based on previous sales data yet. Therefore the company cannot meet all consumer demands, as a result the company will lose 
sales at certain times, which should be a profit. One valuable company asset is raw material. Raw materials is a worth for the company. Without raw materials planning, it is can be uncontrollable, if it is too excessive it will cause storage costs to soaring, but if it cannot be sufficient, the company cannot produce so that it affects production smooth. Recognizing the problems faced, companies must be able to deal with fluctuations in demand by making production planning and raw material requirements planning.

\section{Operation Management}

\section{LITERATUR REVIEW}

Operations management is a series of activities that make goods and services through changes from input to output (Render, Heizel, 2001).

\section{Forecasting}

It is the science of predicting future events. Forecasting requires taking historical data and projecting it to the future with some form of mathematical model (Render, Heizel, pp. 46, 2001).

\section{MRP (Material Requirement Planning)}

Is a dependent inventory model (David W. Pentica, 1979), the use of this model is an effective inventory model, and the conditions must be known:

(a) the main production schedule (what will be made and when is done)

(b) specifications or bill of material

(c) availability of supplies

(d) orders that must be fulfilled

(e) lead time (how long does it take to get various components) 


\section{RESEARCH METHOD}

To facilitate data processing, a research design is needed that can describe a systematic data processing process, as in the following figure.

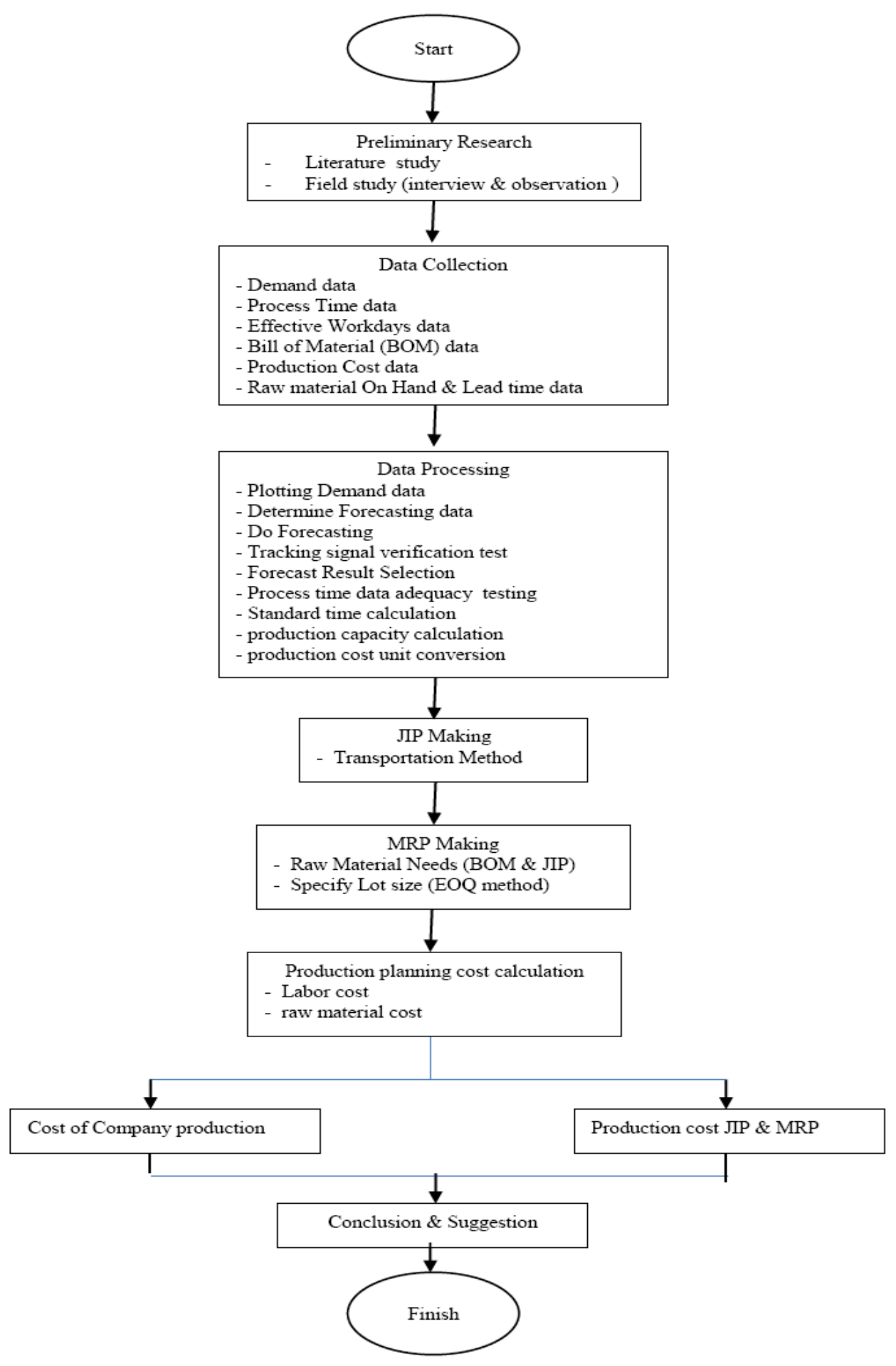

Figure 1. Research Flowchart

RESULTS AND DISCUSSION

To get an analysis and conclusion from this study, then supporting data is needed so that the result can be accounted for both theoretically and applicative in the field. The available data is data sourced from the company, but the presentation is different according to the presentation that I have set in the research method that I do. The supporting data, among others. 


\section{Demand Data}

Demand data for the past period is production data carried out by the company in accordance with demand to determine the extent of demand level during the last period, thus illustration of production will be obtained based on historical demand obtained by the company not too far with the time research was conducted, so that there was a possibility of data irrelevancy due to incompatibility with real conditions.

\section{Forecasting Demand for Livestock Feed Flour}

From the flour feed demand for livestock feed June 2016-May 2017 forecasting is done with the moving average and exponential smoothing methods, this is because the demand data is fluctuating and does not show a linear trend. From demand forecasting that has been carried out for June 2017 to May 2018, the forecasting method was selected for each product, feather flour using the moving average ( $M A=3$ ) method, fish flour using exponential smoothing method ( $\alpha=0.33$ ), bone flour uses exponential smoothing method ( $\alpha=0.33$ ), and crab flour uses exponential smoothing method $(\alpha=0.33)$. Here are the results:

Table 1. The Forecasting of Livestock Feed Flour

\begin{tabular}{|l|c|c|c|c|}
\hline \multirow{2}{*}{\multicolumn{1}{|c|}{ Period }} & \multicolumn{3}{c|}{ The Result of Forecast (kg) } \\
\cline { 2 - 5 } & Feather flour & Fish flour & Bone flour & Crab fluor \\
\hline June 2017 & 191040 & 144876 & 135189 & 158028 \\
\hline July 2017 & 191040 & 144876 & 135189 & 158028 \\
\hline August 2017 & 191040 & 144876 & 135189 & 158028 \\
\hline September 2017 & 191040 & 144876 & 135189 & 158028 \\
\hline October 2017 & 191040 & 144876 & 135189 & 158028 \\
\hline November2017 & 191040 & 144876 & 135189 & 158028 \\
\hline December 2017 & 191040 & 144876 & 135189 & 158028 \\
\hline January 2018 & 191040 & 144876 & 135189 & 158028 \\
\hline February 2018 & 191040 & 144876 & 135189 & 158028 \\
\hline March 2018 & 191040 & 144876 & 135189 & 158028 \\
\hline April 2018 & 191040 & 144876 & 135189 & 158028 \\
\hline May 2018 & 191040 & 144876 & 135189 & 158028 \\
\hline
\end{tabular}

\section{Making Production Master Schedule}

Inputs from the Production Master Schedule are the forecasting result, labor costs and production capacity, production capacity is obtained from effective working days data and data processing time. Before making the Production Master Schedule, it must first make equal the units between forecasting, costs, and production capacity, which in this study used units (kg). From the Production Master Schedule made based on the forecasting result and production capacity, the following results are obtained: 
Tabel 2. Production Master Schedule of CV. Bulu Nusantara June 2017- May 2018

\begin{tabular}{|l|c|c|c|c|}
\hline \multirow{2}{*}{\multicolumn{1}{|c|}{ Period }} & \multicolumn{4}{|c|}{ Production Planning (kg) } \\
\cline { 2 - 5 } & Feather flour & Fish flour & Bone flour & Crab fluor \\
\hline June 2017 & 191040 & 144876 & 135189 & 158028 \\
\hline July 2017 & 191040 & 144876 & 135189 & 160834 \\
\hline August 2017 & 191040 & 147792 & 137658 & 162890 \\
\hline September 2017 & 191040 & 141960 & 132720 & 150360 \\
\hline October 2017 & 191040 & 144876 & 135189 & 162890 \\
\hline November 2017 & 191040 & 153707 & 143188 & 162890 \\
\hline December 2017 & 191040 & 136045 & 127190 & 148304 \\
\hline January 2018 & 191040 & 153707 & 143188 & 162890 \\
\hline February 2018 & 191040 & 136045 & 127190 & 153166 \\
\hline March 2018 & 191040 & 150708 & 140127 & 162890 \\
\hline April 2018 & 191040 & 141960 & 132720 & 153166 \\
\hline May 2018 & 191040 & 141960 & 132720 & 158028 \\
\hline
\end{tabular}

Master Production Schedule above shows that for forecasting requests, production planning is carried out as Table 7 above, so that demand based on forecasting results can be fulfilled with minimum labor costs.

\section{Material Requirement Planning (MRP)}

Before making MRP, you must first determine the raw material requirements and lot size, for material requirements obtained from the Bill of Material and Production Master Schedule. The method employed determine the lot size in this study is EOQ, this is because this method is compatible for planning within the time horizon 1 year. From the MRP, you can see when, how many orders, how many orders for raw materials on a plan order release, and also how many raw materials in the inventory for each month are projected on hand so that the raw material inventory is optimal according to the Production Master Schedule, here are the results:

Table 3 Plan for Order Release \& Projected On Hand of Raw Materials

\begin{tabular}{|c|c|c|c|c|c|c|c|c|c|c|c|c|c|}
\hline \multirow[t]{2}{*}{ Raw material } & \multicolumn{12}{|c|}{ Plan Order Release } & \multirow[t]{2}{*}{ Total } \\
\hline & Jun-17 & Jul-17 & Aug-17 & Sep-17 & Oct-17 & Nov-17 & Dec-17 & Jan-18 & Feb-18 & 11ar-18 & apr-18 & May-18 & \\
\hline Poultry feather & 310297 & & 310297 & 310297 & & 1310.297 & 310197 & & 310297 & 310297 & & & 2. 172079 \\
\hline Fish bone & 330948 & & 330948 & & 330.948 & & & 330948 & & 330948 & & & 1.654740 \\
\hline Cow bone & 319692 & & & 319692 & & 319692 & & 319692 & & A 692 & & & 1. 598460 \\
\hline Shells & 399114 & & & 399114 & & 399114 & & & 399114 & & 399114 & & 1.995570 \\
\hline \multirow{2}{*}{ Raw material } & \multicolumn{12}{|c|}{ Projected On Hand } & \multirow{2}{*}{ Total } \\
\hline & Jun-17 & Jul-17 & Aug-17 & Sep-17 & Oct-17 & Nov-17 & Dec-17 & Jan-18 & Feb-18 & Mar-18 & $1 p r-18$ & May-18 & \\
\hline Poultry feather & 99.408 & 209.113 & 8521 & 118.226 & 227.931 & 127.339 & 137044 & 246.749 & 46.157 & 15a 861 & 265.567 & 64.975 & 1.606 .892 \\
\hline Fish bone & 97880 & 276708 & 121526 & 303416 & 151296 & 320.856 & 178.005 & 16.613 & 204.714 & 46471 & 228361 & 79303 & 2.025 .145 \\
\hline
\end{tabular}

From Table above, in the plan order release section shows that the company must place an order for raw materials in the stated months and the order size stated in the plan order release section in Table 8 . The projected on hand section shows the quantity of raw material expected in inventory at the end of the period, and available for 


\begin{tabular}{|c|c|c|}
\hline \multirow{2}{*}{\multicolumn{3}{|c|}{$\begin{array}{l}\text { Total Labor Cost }=\text { Rp. } \\
\text { Total Cost of Raw Materials }\end{array}$}} \\
\hline & & \\
\hline Poultry Feathers & $=\mathrm{Rp}$. & 2.998.391.900 \\
\hline Fishbone & $=\mathrm{Rp}$. & 5.678 .156 .500 \\
\hline Cow bone & $=\mathrm{Rp}$ & 3.073 .359 .900 \\
\hline Shells & $=\mathrm{Rp}$. & 4.829 .338 .800 \\
\hline Packing Sacks & $=\mathrm{Rp}$ & 130.950 .100 \\
\hline tal Production Plan Cc & : $\mathrm{Rp}$ & 18.568 .254 .83 \\
\hline
\end{tabular}

If the production plan costs results are compared to the company's production costs (labor costs + raw material costs) the year of use in the next period.

\section{Production Cost Calculation}

After obtaining total labor costs and total costs for each raw material, the total production costs can be calculated for the first year (June 2017 - May 2018). Following are the results of the calculation of production costs for the first year: 2016-2017 which amounted to Rp. $18,690,250,000$, the difference will be obtained as follows:

Table 4. Difference in Production Costs 1 Year of Company Version and Planning Production

\begin{tabular}{|c|c|c|}
\hline \multicolumn{2}{|c|}{ Production Costs 1 Year } & \multirow{2}{*}{ Difference } \\
\hline Company & Production plan & \\
\hline Rp 18.690.250.000 & Rp 18.568.254.838 & Rp 121.995.170 \\
\hline
\end{tabular}

\section{CONCLUSION}

Based on the calculation of production planning costs obtained from JIP and MRP, the difference between the cost of Rp 121,995,170 and the company's production costs in 20162017 was obtained. This cost difference shows that if the company plans production using JIP and MRP, a savings of Rp 121,995,170 will be obtained in 1 year.

\section{References}

Baroto, Teguh, 2002. Perencanaan dan Pengendalian Produksi, Jakarta : Ghalia Indonesia

David W. Pentica, 1979. Material Requirements Planning : Journal Hospital Topics 57, pp. 40-43 (May - June 1979)

Gasperz, Vincent. 2004. Production Planning and Inventory Control. Jakart : PT Gramedia Pustaka Utama.

Heizer, Jay, and Bary Render. 1997. Production and Operation Management, Fourth Ed. Upper Saddle River. NJ. Prentice Hall

John G. Wacker. 1985. Effective Planning and Cost Control for Restaurants. Journal Production and Inventory Management. pp. 55-70

Kusuma, Hendra. 2002. Perencanaan dan Pengendalian Produksi. Yogyakarta : Andi.

Makridakis. 1993. Metode dan Aplikasi Peramalan, Jakarta : Bina Aksara.

Nasution, Arman Hakim. 1999. Perencanaan dan Pengendalian Produksi. Jakarta : Guna Widya.

Render, B., and R.M. Stair. 1997. Quantitative Analysis for Management, Sixth Ed. Upper Saddle River, NJ : Prentice Hall.

Sivakumar, R.A., R. Batta and Tehrani. Scheduling Repair at Texas Instruments, Interface 23, No 4 (July - August 1993) pp. 68-74.

Sutalaksana, Iftikar. 1979. Teknik Tata Cara Kerja. Bandung : Institut Teknologi Bandung. 